\title{
Some aspects of the stability of the so-called "Co-Mo-S" phase present in sulfided carbon-supported Co and CoMo catalysts : a Mössbauer emission spectroscopic study
}

\author{
Citation for published version (APA): \\ Crajé, M. W. J., Beer, de, V. H. J., \& Kraan, van der, A. M. (1992). Some aspects of the stability of the so-called \\ "Co-Mo-S" phase present in sulfided carbon-supported Co and CoMo catalysts : a Mössbauer emission \\ spectroscopic study. Hyperfine Interactions, 69(1-4), 799-802. https://doi.org/10.1007/BF02401947
}

DOI:

10.1007/BF02401947

Document status and date:

Published: 01/01/1992

\section{Document Version:}

Publisher's PDF, also known as Version of Record (includes final page, issue and volume numbers)

\section{Please check the document version of this publication:}

- A submitted manuscript is the version of the article upon submission and before peer-review. There can be important differences between the submitted version and the official published version of record. People interested in the research are advised to contact the author for the final version of the publication, or visit the DOI to the publisher's website.

- The final author version and the galley proof are versions of the publication after peer review.

- The final published version features the final layout of the paper including the volume, issue and page numbers.

Link to publication

\footnotetext{
General rights

- You may freely distribute the URL identifying the publication in the public portal. follow below link for the End User Agreement:

www.tue.nl/taverne

\section{Take down policy}

If you believe that this document breaches copyright please contact us at:

openaccess@tue.nl

providing details and we will investigate your claim.
}

Copyright and moral rights for the publications made accessible in the public portal are retained by the authors and/or other copyright owners and it is a condition of accessing publications that users recognise and abide by the legal requirements associated with these rights.

- Users may download and print one copy of any publication from the public portal for the purpose of private study or research.

- You may not further distribute the material or use it for any profit-making activity or commercial gain

If the publication is distributed under the terms of Article $25 \mathrm{fa}$ of the Dutch Copyright Act, indicated by the "Taverne" license above, please 


\title{
SOME ASPECTS OF THE STABILITY OF THE SO-CALLED "Co-MO- S" PHASE PRESENT IN SULFIDED CARBON-SUPPORTED Co AND CoMo CATALYSTS. A MÖSSBAUER EMISSION SPECTROSCOPIC STUDY
}

\author{
M.W.J. CRAJÉ', V.H.J. de BEER ${ }^{2}$ and A.M. van der KRAAN' \\ 'Interfacultair Reactor Instituut, Delft University of Techmology, Mekelweg 15, $2629 \mathrm{JB}$ Delft \\ The Netherlands \\ ${ }^{2}$ Schuit Catalysis Institute, Eindhoven University of Techmology, P.O. Box 513, $5600 \mathrm{MB}$ Eindhoven \\ The Netherlands
}

A relation between the quadrupole splitting (Q.S value) of the "Co-sulfide" phase and its sensitivity to exposure to ambient air could be established by means of Mössbauer emission spectroscopy (MES). For both $\mathrm{Co} / \mathrm{C}$ and $\mathrm{CoMo} / \mathrm{C}$ catalysts showing a quadrupole doublet with a large Q.S. value $(1.20-1.30 \mathrm{~mm} / \mathrm{s})$ air exposure at room temperature for one day did not cause significant changes in the MES spectrum. In the case of catalysts showing a doublet with a smaller Q.S. value, exposure to ambient air resulted in the presence of a high-spin $2+$ doublet. In addition, for these catalysts air contact is found to give rise to an increase of the Q.S. value of the "Co-sulfide" phase which points to an increased dispersion of the "Co-sulfide" phase.

\section{INTRODUCTION}

Hydrotreating catalysts are generally applied to remove heteroatoms from crude oil fractions. Application of in-situ Mössbauer emission spectroscopy (MES) enabled Topsøe et al. /1/ and Wivel et al. $/ 2 /$ to establish a relation between the structural parameters of sulfided CoMo catalysts (the spectral contribution of the so-called "Co-Mo-S" quadrupole doublet) and their thiophene hydrodesulfurization (HDS) activity. The so-called "Co-Mo-S" doublet was originally observed in sulfided CoMo catalysts, but recently van der Kraan et al. /3,4/ observed the same doublet in sulfided $\mathrm{Co} / \mathrm{C}$ catalysts (without $\mathrm{Mo}$ ). The corresponding "Co-Mo-S" species turned out to be an intermediate during the stepwise sulfidation from room temperature to $673 \mathrm{~K}$ of these $\mathrm{Co} / \mathrm{C}$ catalysts. The results of in-situ MES (down $104.2 \mathrm{~K} / 5 /$ ) and EXAFS measurements $16 /$ showed that the "Co-Mo-S" in $\mathrm{Co} / \mathrm{C}$ is equal to that in $\mathrm{CoMo} / \mathrm{C}$. In the present study it is therefore tried to distinguish them chemically. In a previous paper /7/ several aspects of the stability of the "Co-Mo-S" phase in a CoMo/C catalyst at low Co/Mo ratio $(0.0094)$ were discussed. This discussion is now extended to $\mathrm{CoMo} / \mathrm{C}$ catalysts with higher $\mathrm{Co} / \mathrm{Mo}$ ratios and to $\mathrm{Co} / \mathrm{C}$ catalysts.

\section{RESULTS AND DISCUSSION}

For details about catalyst preparation and applied sulfidation procedure see e.g. $/ 4 /$. In the catalyst notation the $\mathrm{Co}$ and Mo contents are given in $4 . \mathrm{F} \%$ and $\mathrm{Co} / \mathrm{Mo}$ stands for the atomic ratio of Co over Mo. Fig. I shows the MES spectra of a $\mathrm{Co}(0.1) \mathrm{Mo}(6.84) / \mathrm{C}$ catalyst sulfided at $673 \mathrm{~K}(\mathrm{~S}, 673 \mathrm{~K})$. It is clear that the MES spectrum is not affected by exposure to ambient air during one day (REOX, $1 \mathrm{D})$, which is in agrecment with earlier findings on a $\mathrm{Co}(0.04) \mathrm{Mo}(6.84) / \mathrm{C}$ catalyst /7/. For this last catalyst it wis found that during exposure for one year the resonant absorption area (RAA) slowly decreased to zero. From fig. 1 it can be seen that also for the Co(0.1)Mo(6.84)/C catalyst the RAA became almost zero after exposure to air for one year (REOX, 1 y). To elucidate whether besides the RAA also the chemical structure was changed, the catalyst was examined at $77 \mathrm{~K}$ and the spectrum in fig. 1 clearly show's the presence of a high-spin $2+$ doublet. Hence, changes in the chemical structure occurred during the one year exposure to ambient air. In fig. 2 the temperature dependence of $\ln (\mathrm{RAA})$ is 

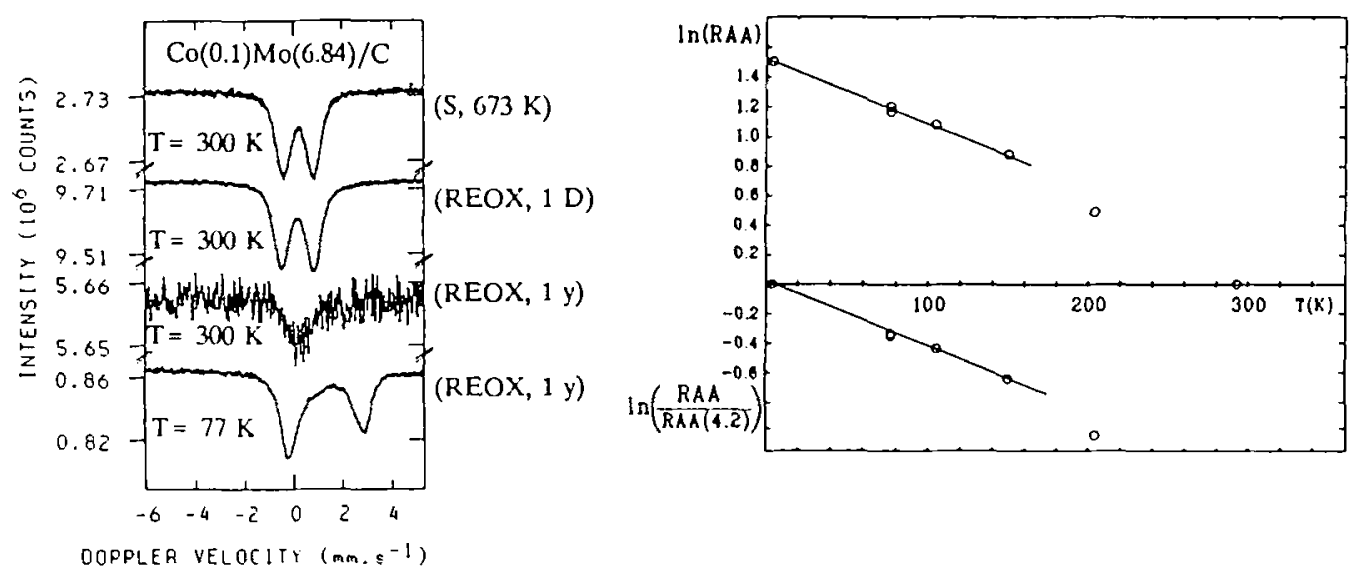

Figure 1. Mössbauer emission spectra of $\mathrm{Co}(0.1) \mathrm{Mo}(6.84) / \mathrm{C}$ sulfided at $673 \mathrm{~K}$ and subsequently exposed to ambient air for one day and one year respectively. The spectra are recorded at the temperature indicated.

Figure 2. Temperature dependence of the RAA of the high-spin $2+$ phase observed for $\mathrm{Co}(0.1) \mathrm{Mo}(6.84) / \mathrm{C}$ exposed to air for one year after stepwise sulfidation up to $673 \mathrm{~K}$.

plotted. A straight line can be fitted through the data obtained between 4.2 and $150 \mathrm{~K}$. From the slope of this line a Debije temperature $\theta_{D}$ of about $175 \mathrm{~K}$ can be derived for this high-spin $2+$ phase. At temperatures above $150 \mathrm{~K}$ the $\theta_{\mathrm{D}}$ decreased markedly. This is in agreement with (but does not prove) our suggestion /7/ that the high-spin $2+$ phase is hygroscopic and that the adsorbed water weakens the interaction between the Co-containing phase and the "MoS particles. Namely, at very low temperatures the water is frozen while it melts at a certain temperature. The melting temperature will be strongly influenced by the concentration of (highspin $2+$ ) ions and can therefore be substantially lower than $273 \mathrm{~K}$.

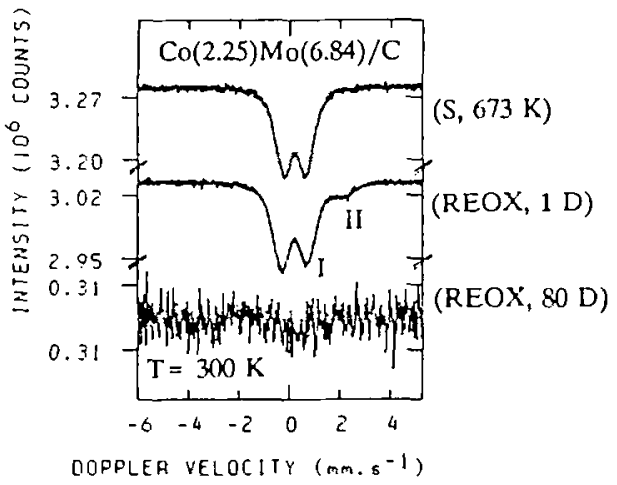

Figure 3. Mössbauer emission spectra of $\mathrm{Co}(2.25) \mathrm{Mo}(6.84) / \mathrm{C}$ sulfided at $673 \mathrm{~K}$ and subsequently exposed to ambient air for one day and 80 days respectively.

In fig. 3 MES spectra of $C o(2.25) \mathrm{Mo}(6.84) / \mathrm{C}$ after sulfidation up to $673 \mathrm{~K}(\mathrm{~S}, 673 \mathrm{~K})$ and subsequent exposure to ambient air are presented. Two doublets are shown in the spectrum after exposure to air (REOX, 1 D). A small high-spin $2+$ contribution obviously originating from Co which is affected by the air (doublet II). The other doublet (doublet I) is characterized by a Q.S. 
value which is larger than the Q.S. value measured directly after sulfidation at $673 \mathrm{~K}(\mathrm{~S}, 673 \mathrm{~K})$. Exposure of the $\operatorname{Co}(2.25) \mathrm{Mo}(6.84) / \mathrm{C}$ catalyst to air for 80 days (REOX, $80 \mathrm{D}$ ) leads to a complete loss of the RAA. Comparison with the results on $\mathrm{Co}(0.04) \mathrm{Mo}(6.84) / \mathrm{C} / 7 /$ learns that the catalyst with the high Joading looses its RAA much faster than that with the low Co-loading.

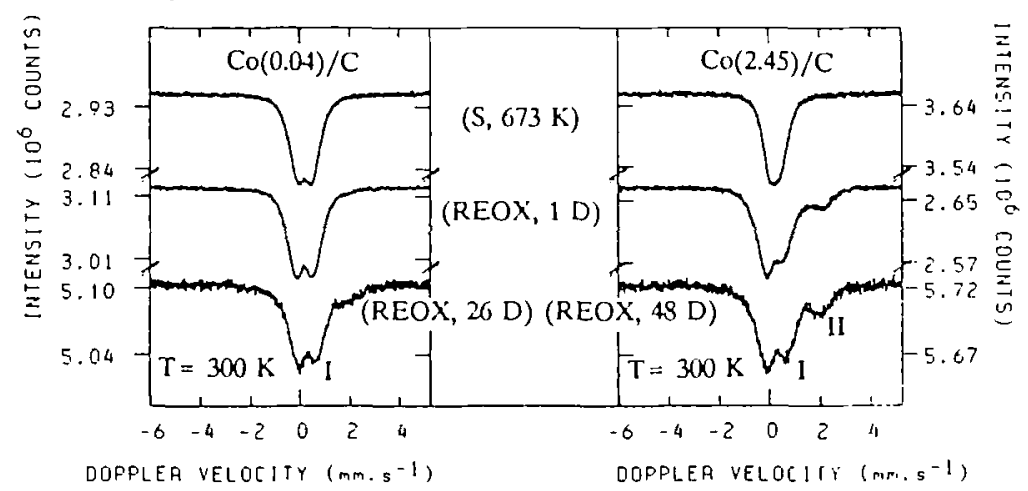

Figure 4. Mössbauer emission spectra of $\mathrm{Co}(0.04) / \mathrm{C}$ and $\mathrm{Co}(2.45) / \mathrm{C}$ sulfided at $673 \mathrm{~K}$ and subsequently exposed to ambient air for one day and 26 or 48 days respectively.

Results obtained on a $\mathrm{Co}(0.04) / \mathrm{C}$ and a $\mathrm{Co}(2.45) / \mathrm{C}$ catalyst are presented in fig. 4 . In the case of $\mathrm{Co}(0.04) / C$ one day exposure (REOX, $1 \mathrm{D}$ ) resulted in an increased Q.S. value but did not lead to the formation of a species characterized by a high-spin $2+$ doublet. After exposure to air for 26 days (REOX, $26 \mathrm{D}$ ), a high-spin $2+$ contribution is measured and though it is not allowed to compare the RAA values (the catalyst has been taken out of the reactor during the 26 days) it can be concluded from the counting statistics that the RAA is decreased markedly. The $\mathrm{Co}(2.45) / \mathrm{C}$ catalyst shows already a high-spin $2+$ contribution after exposure to air for only one day. The relative contribution of the high-spin $2+$ phase has increased during exposure to air for 48 days, and it again can be concluded from the counting statistics that the RAA is decreased. In addition, the Q.S. value of doublet I increases in the following order $(S, 673$ $\mathrm{K})<($ REOX, $1 \mathrm{D})<($ REOX, $48 \mathrm{D})$.

There is a clear trend in the data discussed so far, viz., the smaller the Q.S. value of the "Cosulfide" phase present in the freshly sulfided catalyst $(\mathrm{S}, 673 \mathrm{~K})$ the more sensitive this phase is to ambient air contact. Namely, the smaller this Q.S. value, the higher the tendency for high-spin $2+$ formation, decrease in RAA and increase in the Q.S. value of doublet I of the air exposed sample. Since exposure to air for one year leads to the formation of a $100 \%$ high-spin $2+$ phase and not to an oxidic $3+$ phase, this doublet I must be assigned to a "Co-sulfide" phase. As it was reported by Crajé et al. /8/ that the Q.S. value of the "Co-sulfide" phase is a measure for its dispersion, the increase in Q.S. value after exposure to air, points to an increase of the dispersion of the "Co-sulfide" phase.

In order to confirm this relation a $\mathrm{Co}(0.04) / \mathrm{C}$ catalyst was prepared and split into two samples. One sample was stepwise sulfided up to $473 \mathrm{~K}$ after which it could be characterized by a $100 \%$ "Co-Mo-S" doublet (see fig. 5). Upon exposure to air for one day (REOX, 1 D) the spectrum hardly changed. As was to be expected, the phase causing the large Q.S. value is insensitive to this air exposure. The other sample was again first stepwise sulfided up to $473 \mathrm{~K}$ but it was subsequently kept in the sulfiding gas mixture at $460 \mathrm{~K}$ for $72 \mathrm{~h} / 5 /$. This extended sulfidation has led to a decrease of the Q.S. value which in turn resulted in a higher sensitivity to air exposure (REOX, $1 \mathrm{D})$. Due to this air exposure, the Q.S. value of doublet I has increased markedly and a high-spin $2+$ contribution is clearly present in the spectrum. Furthermore, it can be seen from fig. 5 that resulfidation $(\mathrm{ReS}, 473 \mathrm{~K}$ ) of the air exposed sample led to a spectrum with a Q.S. value which is much larger than the one measured directly after sulfidation at $460 \mathrm{~K}$ 


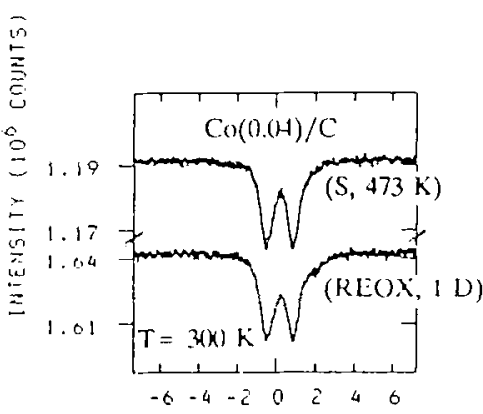

DOFFLER VELOCIYY (mm. $\mathrm{s}^{-1}$ )

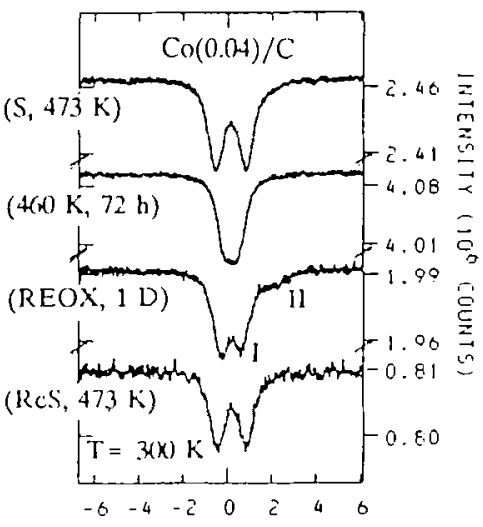

LUOFFER VELDTITY $\left\{m . s^{-1}\right)$

Figure 5. Mössbauer emission spectra of two samples of $\operatorname{Co}(0.04) / \mathrm{C}$ after various successive sulfidation and air exposure treatments.

$\mathrm{K}$. This is a strong indication that indeed the dispersion of the "Co-sulfide" phase increased during exposure of the catalyst to air.

So, it is demonstrated that both $\mathrm{Co} / \mathrm{C}$ and $\mathrm{CoMO} / \mathrm{C}$ catalysts contain a "Co-sulfide" phase the Q.S. value of which correlates with its sensitivity to ambient air contact, viz., the larger the Q.S. value the lower the sensitivity to air. Crajé et al. /8/ have demonstrated that the Q.S. value of the "Co-sulfide" phase is related to its dispersion. The larger the Q.S. value, the higher the dispersion. This indicates that the sensitivity to exposure to ambient air of very highly dispersed "Co-sulfide" is low, whereas it is high for less well dispersed "Co-sulfide". Upon exposure to air of these less well dispersed "Co-sulfide" very rapidly a high-spin $2+$ doublet appeared in the spectrum and the Q.S. value of the sulfidic doublet I increased. A similar effect of sensitivity for $\mathrm{H}_{2}$ was observed by Christensen et al. /9/, who found that "Co-sulfide" characterized by a smaller Q.S. value could be reduced more easily in $\mathrm{H}_{2}$ than the one characterized by a larger Q.S. value.

\section{REFERENCES}

1/ H. Topsse, B.S. Clausen, R. Candia, C. Wivel and S. Morup, J. Catal., 68(1981)433.

/2/ C. Wivel, R. Candia, B.S. Clausen and H. Topsoe, J. Catal., 68(1981)453.

/3/ A.M. van der Kraan, M.W.J. Crajé, E. Gerkema, W.L.T.M. Ramselaar and V.H.J. de Beer, Appl. Catal., 39(1988)L7.

14/ A.M. van der Kraan. M.W.J. Crajé, E. Gerkema, W.L.T.M. Ramselaar and V.H.J. de Beer, Hyp. Int., 46(1989)567.

15/ M.W.J. Crajé. V.H.J. de Beer and A.M. van der Kraan, Appl. Catal., 70(1991)L7.

/6/ M.W.J. Crajé, S.P.A. Louwers, V.H.J. de Beer, R. Prins and A.M. van der Kraan, to be published.

/7/ M.W.J. Crajé, E. Gerkema, V.H.J. de Beer and A.M. van der Kraan, Hyp. Int., 57(1990) 1795 .

18/ M.W.J. Crajé, V.H.J. de Beer and A.M. van der Kraan, To be published, Bull. Soc. Chim. Belg., (1991).

19/ P.H. Christensen, S. Mørup, B.S. Clausen and H. Topsse, in:"Proc. Int. Conf. on the Appl. of the Mössbauer Effect.", Alma Ata, USSR 1983, Gordon \& Breach Sci. Publ., 3(1985)1101. 